\title{
The school readiness instrument (SRI): assessment of early childhood in the neuroscience perspective
}

\author{
Ruqoyyah Fitri, Muhammad Reza \\ Universitas Negeri Surabaya \\ Surabaya, Indonesia \\ ruqoyyahfitri@unesa.ac.id
}

\begin{abstract}
This study aims to develop the School Readiness Instrument (SRI) using a neuroscience perspective to measure the readiness of the child to the primary school designed to make it easier for teachers and parents to assess child development through their daily performance observations. The method used is following the ADDIE model design with the subject of 50 children aged 5-6 years. Preliminary analysis demonstrates the need for three domains: motor development, cognitive and language, and self-regulation for learning readiness. The results of validity reveal changes to five more detailed SRI domains: motor development, cognitive and language, social development, emotional maturity, and learning involvement. Trials were conducted in two groups with high and low development outcomes. Interrater reliability shows consistency between two observers. From these results indicate that SRI is an appropriate instrument to be used as a measure of early childhood school readiness.
\end{abstract}

Keywords—school readiness; instrument; neuroscience

\section{INTRODUCTION}

The school readiness instrument (SRI) is a measure of the readiness of early childhood schools from a neuroscientific perspective. Early childhood learning readiness is the readiness to learn to enter elementary school (SD). Reference [1] school readiness is defined as a multidimensional concept that considers the behavioral aspects and cognitive development of children and adaptation of children when in the classroom. In early childhood needs to be assessed to see the readiness of learning for special actions can be done if there is a mark difference in ability than his age. Assessments to see early childhood readiness generally focus on measures of children's pre-academic abilities and behaviors [2].

To measure learning readiness, one of the most popular tests used today is the NST "Nijmeegse Schoolbekwaamheids Test". The test compiled by Prof. Dr. F.J. Monks, Drs. H. Rost and Drs. N.H. Coffie. NST developed in Nijmegen - Nederland is a Gopinger test processing from Germany [3]. The use of NST tests to measure early childhood learning readiness can only be done by psychological institutions so that not all teachers or parents can use this tool. Though there is the need for parents and teachers to be able to know the readiness of learning children because it plays a role in the form of support and stimulation support to children. Therefore, reference [4] required measuring tools designed to provide informative, inexpensive and psychometric tools for assessing child readiness.

The purpose of this research is to develop early childhood school preparation (SRI) instrument to elementary school according to neuroscience perspective. In the view of the science of neuroscience, readiness is defined as the ability of the early processes of brain work to think, so it is said that this ability is closely related to cognitive intelligence [5]. Children are said to have the readiness to learn if they have selfregulating ability to enable children to engage in learning (eg, attention, perseverance, behavior in task, learning behavior) [6]; [7], has higher abilities in mathematics and reading as well as learning involvement such as: attention, persistence, behavior in task, and learning behavior [8], has many vocabularies, has social-emotional skills [9], aggressive behavior is reduced [10], has better self-control [11] / has emotional control, and is able to organize and adapt his emotions to something faced, has prosocial behavior [12]; [13], able to work in group / cooperative play [11].

Based on the opinions of these experts it can be concluded that early childhood learning readiness can be characterized by its ability in academic aspects (mathematics and reading), involvement in learning, and social and emotional skills. But the opinion has not included aspects of physical motor readiness should also be a marker of learning readiness of children. Given that the child is said to have the readiness to enter the elementary school level is the same as having the maturity of development according to the stage of his age.

Reference [14] children's learning readiness coexist with their development. The development of the middle toward the end of the age of children who are the age to elementary school where children are in the age range 6-11 years who have more refined and more coordinated motor development, begin to have control over their bodies so that it can sit or stand in time longer, able to concentrate, experiencing development in communication/language, memory development especially on things he sees and hears, critical thinking, self-understanding, prosocial attitude, and emotional control, and has the skills in reading, writing, and arithmetic.

In preparing this instrument of learning readiness using the perspective of neurosis because neuroscience is one branch of science that focuses on getting to know more about the brain and nervous system. This science is very useful in recognizing 
child development [15]. Children are said to develop when experiencing nerve maturity due to the integration of brain functional function based on stimulation received by individuals [16]. This maturation process occurs gradually starting from the maturation of sensory systems or sensory functions that form the basis for further maturation process that leads to learning readiness.

Achieving learning readiness is the culmination of cognitive intelligence. The process of brain nerve maturity to cognitive intelligence is influenced by the intelligence of motion. In the brain, there is a system of neurons called basal ganglia that governs the interaction between cognitive and motoric [17]; [18]. Basal ganglia serve to control cognition, movement coordination, and unconscious movement. Reference [19] states that the speed of motor development achievement as a determinant of faster cognitive development associated with cognitive performance in some domains, such as executive function. That includes cognitive performance such as attention, working memory, perception and information processing.

\section{METHOD}

The research method used refers to the design of the ADDIE model [20], which uses 5 development steps namely analysis-design-develop-implement-evaluate.

\section{A. Analyze}

These stages do some analysis: (1) obstacles that occur in the potential development and readiness of early childhood learning during this time, (2) the analysis of learning objectives, and (3) teacher constraints in measuring child's learning readiness. The results of this analysis are used as a benchmark for preparing instrument grain readiness early childhood learning, as well as guidelines to form the instrument that will be developed.

\section{B. Design}

Performing the initial design of SRI instrument design include: (1) formulating goals to be achieved that are adjusted to the standard of achievement level of development of children aged 5-6 years; (2) collecting theories about early childhood readiness for constructive materials in the making of indicators; (3) designing the grille in accordance with the indicators that have been prepared.

\section{Develop}

Realizing SRI instrument design by: (1) arranging SRI instruments in the form of non-tests in the form of performance using rating scale between 1-4 with the criteria of assessment, (2) validate to measure the feasibility of the SRI instrument, (3) revise the instrument based on the suggestion of the validator, (4) a limited trial of 10 children with 5 children with high achievement outcomes and 5 children with lower development outcomes; 5) reliability test along with a limited trial, and (6) test of the practicality of SRI instruments.

\section{Implement}

At this stage, a trial of 50 early-age children of 5-6 years old age group was performed.

\section{E. Evaluate}

To evaluate all phases from phase 1 to stage 4 . In stage 4, evaluation is done in the form of analysis of the implementation results in the research subjects.

In this study, data collection using observation techniques, unstructured interviews, instrument validation, observation sheet of the development results. The data analysis technique uses the source triangulation technique, validation technique from the validator to see the validity of each instrument item developed (qualitative grain analysis), and reliability (KK Cohen-Kappa / Experts Agreement) by combining the first observer result and the second observer on the performance of the child using SRI revised instruments were analyzed in conjunction with the SPSS program. Test the practicality of the instrument by giving a questionnaire to the teacher who made the observation using the SRI instrument to assess the instrumentality of the instrument when used measures the readiness of early childhood learning.

\section{RESUlT AND DisCUSSION}

The results of the triangulation method of observation, interviews and documentation studies show that the teacher does not yet have an instrument for assessing learning readiness. To assess children's learning readiness must be done through collaboration with psychological institutions in the form of NST tests and the costs borne by parents. Thus, children from poor parents do not have the opportunity to get a learning readiness assessment. While the teacher has not been able to do the measurement alone because there is no instrument that does not require costly and is practical to use to measure children's learning readiness.

Based on the analysis of the learning objectives that children aged 5-6 years in accordance with standards of developmental attainment level [21], should have the achievement of physical motor development include: having the ability of body movement is coordinated, flexible, balanced, and agile and follow the rules; using tools to explore and express themselves in various forms; to live clean, healthy, and caring for safety. In the cognitive aspect has the achievement: solve simple problems, logical thinking, and symbolic thinking. Language aspects include understanding language, expressing language, and literacy. On the emotional social aspect should have self-awareness, sense of responsibility, prosocial behavior. In the art, aspect includes: explore, express yourself, and appreciate the work.

The results of the learning objective analysis show that early childhood school readiness should be in line with the achievement of development [22]. Some of the achievements of child development along with school readiness refers to the results of research covering five aspects: physical well-being and motor development, emotional health and positive approaches to new experiences, age-appropriate knowledge and social competence, age-appropriate language skills, and 
general knowledge and cognitive skills according to age [23]; [24]. In the design phase of this study, the indicators are derived from several theories and results of research, as stated by the development and policy researcher of the children who emphasized the need to assess some indicators to get a comprehensive picture of school readiness, namely: socioemotional and cognitive children [25]; [26]; [27]; [28] Ability of independence and language skills [29]; [30]; [31], and the ability of self-regulation [32]; [33]; [34]. Through selfregulating ability allows the child to engage in learning (eg, attention, perseverance, behavior in the task, learning behavior) [7]; [35]

Looking at some of the statements of experts and according to the theoretical analysis of early childhood learning readiness measurements that have been described, it can be concluded that to assess the readiness of early childhood learning can use the criteria of measurement that include aspects: (1) physical and motor development, (2) cognitive development and language, (3) social development, (4) emotional maturity, (5) learning involvement.

Furthermore, the preparation of the lattice, making the observation sheet, making items of child performance items, and making the assessment criteria. Reference [36] is stated score $4=$ when the child is consistent according to item statement; score $3=$ when developing according to statement items; score 2 = when the child is beginning/performing according to the item statement; score $1=$ if the child does not appear to do the item statement.

The formulation of the lattice adjusted to the perspective of neuroscience as the following table.

TABLE I. GRATING SCHOOL READINESS INSTRUMENT (SRI)

\begin{tabular}{|c|c|c|c|}
\hline No & Aspek & Indikator & $\begin{array}{c}\text { Jumlah } \\
\text { Item }\end{array}$ \\
\hline 1 & $\begin{array}{l}\text { Physical and } \\
\text { motor } \\
\text { development }\end{array}$ & $\begin{array}{l}\text { Have a coordinated body movement } \\
\text { characterized by flexibility, balance, and } \\
\text { good agility. }\end{array}$ & 9 \\
\hline \multirow[t]{4}{*}{2} & \multirow{4}{*}{$\begin{array}{l}\text { Cognitive and } \\
\text { language } \\
\text { development }\end{array}$} & Using the language correctly. & 7 \\
\hline & & Basic literacy and literacy skills. & 7 \\
\hline & & Basic mathematical skills. & 13 \\
\hline & & Problem-solving skill. & 4 \\
\hline 3 & $\begin{array}{c}\text { Social } \\
\text { development }\end{array}$ & $\begin{array}{l}\text { Have prosocial behavior, cooperate in } \\
\text { group/play cooperatively. }\end{array}$ & 7 \\
\hline 4 & $\begin{array}{c}\text { Emotional } \\
\text { maturity }\end{array}$ & $\begin{array}{l}\text { Have better self-control and adjust his } \\
\text { emotions to something he faces. }\end{array}$ & 6 \\
\hline \multirow[t]{2}{*}{5} & \multirow{2}{*}{$\begin{array}{l}\text { Learning } \\
\text { engagement }\end{array}$} & Want to get involved in activities at school. & 3 \\
\hline & & Have a focus on the ability to pay attention. & 2 \\
\hline
\end{tabular}

Furthermore, the validity of the content by the evaluation experts and material experts. Because this instrument is in the form of a non-test, the form of item analysis uses qualitative item analysis techniques [37].

Based on the results of content validity, the items that are less valid and invalid are revised by changing the structure of the sentence, adding an example of the child's behavior in the sentence or removing the item and replacing it according to the notes and input of the validator.

A small group trial was conducted using SRI instruments in 10 children with 5 children with high development achievement and 5 low achievement children. Based on the results of the trial can be seen suitability, children who have higher development achievement to obtain high SRI scores are
95, 97.5, 98, 97.5 and 97, while children who have lower development outcomes obtained a lower SRI score of 80,80 , 74,80 , and 84 .

Implementation of reliability together with small group trials. Reliability techniques use the Cohen's Kappa coefficients to measure the degree of agreement of two assessors [37]. The scores obtained were analyzed using statistics yielding the following data.

TABLE II. CROSSTABULATION

\begin{tabular}{|c|c|c|c|c|c|}
\hline \multirow[t]{2}{*}{ Count } & & \multicolumn{3}{|c|}{ Observer 1} & \multirow[b]{2}{*}{ Total } \\
\hline & & 2 & 3 & 4 & \\
\hline \multirow[t]{3}{*}{ Observer 2} & 2 & 3 & 3 & 0 & 6 \\
\hline & 3 & 0 & 33 & 3 & 36 \\
\hline & 4 & 0 & 0 & 8 & 8 \\
\hline \multicolumn{2}{|c|}{ Total number } & 3 & 36 & 11 & 50 \\
\hline
\end{tabular}

Based on Table III shows an agreement between two observers of 50 items of SRI items, agreement of score 2 of 3 items item; agreement score 3 as many as 33 items; deal value 4 as many as 8 items. The difference of score between two observers is 2 and 3 score 3 items; scores 3 and 4 as many as 3 items. As for the acquisition of Cohen's Kappa value according to the following table.

TABLE III. SYMMETRIC MEASURES

\begin{tabular}{|c|c|c|c|c|c|}
\hline & & Value & $\begin{array}{c}\text { Asymp. Std. }_{\text {Error }^{\mathbf{a}}} \\
\text { Approx. T }\end{array}$ & $\begin{array}{c}\text { Approx. } \\
\text { Sig. }\end{array}$ \\
\hline $\begin{array}{c}\text { Nominal by } \\
\text { Nominal }\end{array}$ & Phi & 1.064 & & & .000 \\
\hline & Cramer's V & .752 & & & .000 \\
\hline & $\begin{array}{c}\text { Contingency } \\
\text { Coefficient }\end{array}$ & .729 & & & .000 \\
\hline $\begin{array}{c}\text { Measure of } \\
\text { Agreement }\end{array}$ & Kappa & .727 & .103 & 6.681 & .000 \\
\hline \multicolumn{2}{|c|}{ N of Valid Cases } & 50 & & \\
\hline
\end{tabular}

Based on Table III shows the value of Cohen's Kappa of 0.727. When interpreted, the agreement of two observers indicates a high correlation category, according to the reliability table [37] as follows.

TABLE IV. RELIABILITY TABLE

\begin{tabular}{|c|c|}
\hline Reliability Coefficient & Significance \\
\hline $\mathbf{0 . 0 0} \leq r \leq \mathbf{0 . 1 9}$ & The correlation is very low \\
\hline $\mathbf{0 . 2 0} \leq r \leq \mathbf{0 . 3 9}$ & Low correlation \\
\hline $\mathbf{0 . 4 0} \leq r \leq \mathbf{0 . 6 9}$ & Correlation is enough \\
\hline $\mathbf{0 . 7 0} \leq r \leq \mathbf{0 . 8 9}$ & High correlation \\
\hline $\mathbf{0 . 9 0} \leq r \leq \mathbf{1 . 0 0}$ & The correlation is very high \\
\hline
\end{tabular}


Results of large-scale trials of SRI instruments with the subject of 50 children aged 5-6 years obtained data as follows.

TABLE V. LARge SCALE TRIAl Results

\begin{tabular}{|c|c|c|c|c|c|}
\hline \multirow{2}{*}{ No } & \multirow{2}{*}{ Aspect } & \multicolumn{4}{|c|}{ Amount child achievement } \\
\hline & & Consistent & Growing & $\begin{array}{l}\text { Early } \\
\text { stage }\end{array}$ & Invisible \\
\hline 1 & $\begin{array}{l}\text { Physical and } \\
\text { motor } \\
\text { development }\end{array}$ & 44 & 2 & 4 & - \\
\hline & $\% \mathrm{~N}=50$ & 88 & 4 & 8 & \\
\hline 2 & $\begin{array}{l}\text { Cognitive and } \\
\text { language } \\
\text { development }\end{array}$ & 45 & 4 & 1 & \\
\hline & $\% \mathrm{~N}=50$ & 90 & 8 & 2 & \\
\hline 3 & $\begin{array}{c}\text { Social } \\
\text { development }\end{array}$ & 45 & 2 & 3 & 1 \\
\hline & $\% \mathrm{~N}=50$ & 90 & 4 & 6 & 2 \\
\hline 4 & $\begin{array}{c}\text { Emotional } \\
\text { maturity }\end{array}$ & 41 & 7 & 1 & 1 \\
\hline & $\% \mathrm{~N}=50$ & 82 & 14 & 2 & 2 \\
\hline 5 & $\begin{array}{c}\text { Learning } \\
\text { engagement }\end{array}$ & 43 & 5 & 2 & \\
\hline & $\% \mathrm{~N}=50$ & 86 & 10 & 4 & \\
\hline & $\begin{array}{l}\text { apan belajar } \\
(\%)\end{array}$ & 87,2 & 8 & 4,4 & 2 \\
\hline
\end{tabular}

According to on Table $\mathrm{V}$ shows that the results of a largescale trial using SRI instruments on 50 subjects can be known readiness of children aged 5-6 years as much as $87.2 \%$ while those who have not had readiness (Growing, Early stage, Invisible) as much as $14.4 \%$.

\section{CONCLUSION}

According to on the results of research and discussion concluded that the results of the development of SRI instruments are valid and reliable can be used to measure the readiness of children aged 5-6 years in accordance with the achievements of development. This study provides a practical, inexpensive, and convenient tool for teachers to use without having to find a specific time to assess child's learning readiness as not a test but a measure of performance. With the ease for teachers and parents in using this SRI instrument is expected to improve the way of giving stimulation in children so that children who have not completed the readiness of learning can be given stimulation as needed.

\section{ACKNOWLEDGMENT}

This measurement of learning readiness instrument is composed of the great motivation of early childhood education teachers to have practical and easy-to-use instruments. For that, the authors are thankful to all involved in the preparation, especially to my husband, lecturers, friends of all, my students and teachers of early childhood education who helped until the compilation of this work.

\section{REFERENCES}

[1] F. Parker, A. Boak, K. Griffin, C. Ripple, \& P. Lenora, "Parent-child relationship, home learning environment, and school readiness," School Psychology Review, 28(3), p. 413-425. 1999.
[2] K. La Paro \& R. Pianta, "Predicting children's competence in the early school years: A meta-analytic review," Review of educational research, 70(4), p. 443-484. 2000.

[3] W. Sulistyaningsih, "Kesiapan bersekolah ditinjau dari jenis pendidikan pra sekolah anak dan tingkat pendidikn orangtua," Psikologia, 1 (1), p. 1-8. 2005.

[4] M. Janus \& D. Offord, "Development and psychometric properties of the Early Development Instrument (EDI): A measure of children's school readiness," Canadian Journal of Behavioural Science / Revue canadienne des sciences du comportement, 39(1), p. 1-22. (2007).

[5] J. Welsh, R. Nix, C. Blair, K. Bierman \& K. Nelson, "The development of cognitive skills and gains in academic school readiness for children from low-income families," Journal of educational psychology, 102(1), p. 43.2010.

[6] R. Abenavoli, M. Greenberg, \& K. Bierman, "Identification and validation of school readiness profiles among high-risk kindergartners." Early Childhood Research Quarterly, 38(1), p. 33-43. 2017.

[7] C. Blair, \& C. Raver, "School readiness and self-regulation: A developmental psychobiological approach," Annual Review of Psychology, 66, p. 711-731. (2015).

[8] G. Duncan, C. Dowsett, A. Claessens, K. Magnuson, A. Huston, P. Klebanov, \& H. Sexton, "School readiness and later achievement," Developmental psychology, 43(6), p. 1428-1446. 2007.

[9] P. Goble, L. Hanish, C. Martin, N. Eggum-Wilkens, S. Foster, \& R. Fabes, "Preschool contexts and teacher interactions: Relations with school readiness," Early Education and Development, 27(5), p. 623-641. 2016.

[10] K. Snow, "Integrative view of the domains of child function: Unifying school readiness". In R. C. Pianta, M. J. Cox, \& K. L. Snow (Eds.), "School readiness and the transition to kindergarten in the era of accountability”, (pp. 197-216). 2007. Baltimore, MD: Paul H Brooks Publishing.

[11] L. Marotz, \& K. Allen, “ Developmental profiles pre-birth through adolescence," 7th edition. USA: Wadsworth, Cengage Learning. 2013.

[12] C. Trentacosta, \& S. Fine, "Emotion knowledge, social competence, and behavior problems in childhood and adolescence: A meta-analytic review," Social Development, 19(1), p. 1-29. 2010.

[13] S. Denham, K. Blair, E. DeMulder, J. Levitas, K. Sawyer, S. AuerbachMajor, \& P. Queenan, "Preschool emotional competence: Pathway to social competence?," Child development, 74(1), p. 238-256. 2003.

[14] J. Santrock, "life span developmen perkembangan masa hidup", Alih bahasa Achmad Chusairi, Edisi kelima, Jilid 1. Jakarta: Erlangga. 1995.

[15] C. A. Nelson, \& F. E. Bloom, "Child development and neuroscience,' Child development, 68(5), p. 970-987, 1997.

[16] C. Blair, "School readiness: Integrating cognition and emotion in a neurobiological conceptualization of children 's functioning school entry," American psychologist, 57(2), p. 111, 2002.

[17] G. Leisman, O. Braun-Benjamin, \& R. Melillo, "Cognitive-motor interactions of the basal ganglia in development," Frontiers in systems neuroscience, 8 (16), p. 1-18, 2014.

[18] G. Leisman, \& R. Melillo, "The basal ganglia: motor and cognitive relationships in a clinical neurobehavioral context," Reviews in the Neurosciences, 24(1), p. 9-25. 2013.

[19] G. K. Murray, J. Veijola, K. Moilanen, J. Miettunen, D. C. Glahn, T. D. Cannon, "Infant motor development is associated with adult cognitive categorisation in a longitudinal birth cohort study." J. Child Psychol. Psychiatry 47, p. 25-29, 2006.

[20] R. M. Branc, "Instructional design: The ADDIE approach," New York: Springer, 2010.

[21] Peraturan Menteri Pendidikan dan Kebudayaan Republik Indonesia Nomor 137 Tahun 2014 tentang Standar Nasional Pendidikan Anak Usia Dini.

[22] J. W. Santrock, "life span developmen, perkembangan masa hidup," Alih bahasa Achmad Chusairi, Edisi kelima, Jilid 1. Jakarta: Erlangga, 1995. 
[23] S. Kagan, "Readiness past, present, and future: Shaping the agenda.," Young Children, 48(1), p. 48-53. 1992

[24] G. Doherty, "Zero to six: The basis for school readiness. Ottawa," ON: Human Resources Development Canada. R-97-8E. 1997.

[25] S. Denham, "The emotional basis of learning and development in early childhood education". In B. Spodek \& O. N. Saracho (Eds.), Handbook of research on the education of young children (pp. 85-103). Mahwah, NJ: Erlbaum. 2006.

[26] C. Horton, \& B. Bowman, "Child assessment at the preprimary level: Expert opinion and state trends," Chicago: Herr Research Center at the Erikson Institute. 2002.

[27] C. Raver, \& E. Zigler, "Social competence: An untapped dimension in evaluating Head Start's success," Early Childhood Research Quarterly, 12(4), p. 363-385. 1997.

[28] R. Thompson, \& H. Raikes, "The social and emotional foundations of school readiness," In D. F. Perry, R. K. Kaufmann, \& J. Knitzer (Eds.), Social and emotional health in early childhood: Building bridges between services and systems (pp. 13-35). Baltimore: Brookes. 2007.

[29] J. Beitchman, B. Wilson, E. Brownlie, H. Walters, \& W. Lancee, "Longterm consistency in speech/language profiles: I. Developmental and academic outcomes," Journal of the American Academy of Child \& Adolescent Psychiatry, 35(6), p. 804-814. 1996.

[30] A. Brandone, S. J. Salkind, R. M. Golinkoff, \& K. Hirsh-Pasek, K. "Language development. In G. G. Bear \& K. M. Minke (Eds.)," Children's needs III: Development, prevention, and intervention (pp. 499-514). Washington, DC: National Association of School Psychologists. 2006.

[31] B. Hart, \& T. R. Risley, "Meaningful differences in the everyday experience of young American children," Baltimore: Brookes. 1995.

[32] P. A. Graziano, R. D. Reavis, S. P. Keane, \& S. D. Calkins, "The role of emotion regulation in children's early academic success," Journal of School Psychology, 45(1), p. 3-19, 2007.
[33] C. C. Raver, E. K. Blackburn, M. Bancroft, \& N. Torp, "Relations between effective emotional self-regulation, attentional control, and lowincome preschoolers' social competence with peers," Early Education and Development, 10(3), p. 333-350, 1999.

[34] S. E. Rimm-Kaufman, \& J. Kagan, "Infant predictors of kindergarten behavior: The contribution of inhibited and uninhibited temperament types," Behavioral Disorders, 30(4), p. 331-347, 2005.

[35] R. M. Abenavoli, M. T. Greenberg, \& K. L. Bierman, "Identification and validation of school readiness profiles among high-risk kindergartners," Early Childhood Research Quarterly, 38(1), 33-43. 2017.

[36] Couglin, P. A., Hansen, K. A., Heller, D., Kaufmann, R. K., Stolberg, J. R \& Wash, K. B (2004). Menciptakan kelas yang berpusat pada anak. Wasington DC: Children's Resources International, INC.

[37] I. Basuki, \& Haryanto. "Assesmen pembelejaran," Bandung: PT. Remaja Rosdakarya, 2014 